\title{
The Growth of Steroidobacter agariperforans sp. nov., a Novel Agar-Degrading Bacterium Isolated from Soil, is Enhanced by the Diffusible Metabolites Produced by Bacteria Belonging to Rhizobiales
}

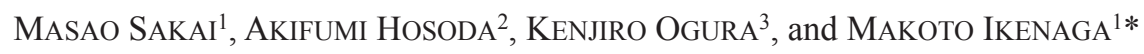 \\ ${ }^{1}$ Faculty of Agriculture, Kagoshima University, 1-21-24, Korimoto, Kagoshima 890-0065, Japan; ${ }^{2}$ School of Agriculture, \\ Meijo University, 1-501 Shiogamaguchi, Tenpaku-ku, Nagoya, Aichi 468-8502, Japan; and ${ }^{3}$ Graduate School of Bioresource \\ and Bioenvironmental Sciences, Kyushu University, 6-10-1, Hakozaki, Higashi-ku, Fukuoka 812-8581, Japan
}

(Received November 29, 2013 -Accepted January 13, 2014-Published online March 13, 2014)

An agar-degrading bacterium was isolated from soil collected in a vegetable cropping field. The growth of this isolate was enhanced by supplying culture supernatants of bacteria belonging to the order Rhizobiales. Phylogenetic analysis based on 16S rRNA gene sequences indicated the novel bacterium, strain $\mathrm{KA} 5-\mathrm{B}^{\mathrm{T}}$, belonged to the genus Steroidobacter in Gammaproteobacteria, but differed from its closest relative, Steroidobacter denitrificans FS ${ }^{\mathrm{T}}$, at the species level with $96.5 \%$ similarity. Strain KA5-B ${ }^{\mathrm{T}}$ was strictly aerobic, Gram-negative, non-motile, non-spore forming, and had a straight to slightly curved rod shape. Cytochrome oxidase and catalase activities were positive. The strain grew on media containing culture supernatants in a temperature range of $15-37^{\circ} \mathrm{C}$ and between $\mathrm{pH} 4.5$ and 9.0 , with optimal growth occurring at $30^{\circ} \mathrm{C}$ and $\mathrm{pH}$ 6.0-8.0. No growth occurred at 10 or $42^{\circ} \mathrm{C}$ or at $\mathrm{NaCl}$ concentrations more than $3 \%(\mathrm{w} / \mathrm{v})$. The main cellular fatty acids were iso- $\mathrm{C}_{15: 0}, \mathrm{C}_{16: 1} \omega 7 \mathrm{c}$, and iso- $\mathrm{C}_{17: 1} \omega 9 \mathrm{c}$. The main quinone was ubiquinone- 8 and DNA $\mathrm{G}+\mathrm{C}$ content was $62.9 \mathrm{~mol} \%$. In contrast, strain $\mathrm{FS}^{\mathrm{T}}$ was motile, did not grow on the agar plate, and its dominant cellular fatty acids were $\mathrm{C}_{15: 0}$ and $\mathrm{C}_{17: 1} \omega 8 \mathrm{c}$. Based on its phylogenetic and phenotypic properties, strain KA5-B ${ }^{\mathrm{T}}\left(\mathrm{JCM} 18477^{\mathrm{T}}=\mathrm{KCTC} 32107^{\mathrm{T}}\right)$ represents a novel species in genus Steroidobacter, for which the name Steroidobacter agariperforans sp. nov. is proposed.

Key words: agar-degrading bacterium, Gammaproteobacteria, novel species, Steroidobacter

Several types of agarase-producing bacteria that degrade and utilize agar have been isolated to date. The most recently reported agar-degrading bacteria have generally been isolated from marine environments $(4,25,28)$. Agar is a polysaccharide produced by marine red algae; therefore, it is reasonable to assume that most agar-degrading bacteria inhabit marine ecosystems. On the other hand, several agar-degrading bacteria have previously been isolated from non-marine environments, including Cytophaga sp. and Alteromonas sp., which were isolated from freshwater sources (1), Spirochaeta alkalica, from soda lakes (46), and Bacillus sp., Cytophaga sp., and Streptomyces coelicolor, from soil $(17,35,43)$. We also recently reported the existence of agar-degrading bacteria in plant rhizospheres $(15,16)$. Mucilage polysaccharides (the structure of which are unknown) secreted from plant roots have been shown to contain abundant amounts of galactose as their main sugar component $(3,5,21,26)$, which suggests that agar-like polysaccharides may be present in plant rhizospheres. The agardegrading enzymes of these isolates may degrade mucilage polysaccharides. Previous studies on agar-degrading bacteria have provided an insight into the ecology of non-marine agar-degrading bacteria.

We isolated a novel agar-degrading bacterium from the soil of a vegetable cropping field. The agarolytic isolate, designated strain $\mathrm{KA} 5-\mathrm{B}^{\mathrm{T}}$, did not grow well on any media, but exhibited a commensal interaction with a bacterium belonging to the order Rhizobiales. Consequently,

\footnotetext{
* Corresponding author. E-mail: ikenaga@agri.kagoshima-u.ac.jp;
} Tel: +81-99-285-8660; Fax: +81-88-285-8661. strain KA5- $\mathrm{B}^{\mathrm{T}}$ was successfully isolated using a medium containing culture supernatant of this bacterium. The $16 \mathrm{~S}$ rRNA gene sequence of strain KA5- $\mathrm{B}^{\mathrm{T}}$ was classified into genus Steroidobacter in Gammaproteobacteria. However, it was significantly differentiated from its closest relative, Steroidobacter denitrificans $\mathrm{FS}^{\mathrm{T}}$ (8), which is the sole species within this genus, at the species level. The aim of the present study was to investigate the commensal interaction between strain $\mathrm{KA} 5-\mathrm{B}^{\mathrm{T}}$ and its companions and determine the taxonomic status of this strain in the genus Steroidobacter using a polyphasic approach. Strain KA-5B $\mathrm{B}^{\mathrm{T}}$ formed a novel species, for which the name Steroidobacter agariperforans sp. nov. is proposed.

\section{Materials and Methods}

Soil collection and cultivation after enriching agar-degrading bacteria

An agar-degrading bacterium, strain $\mathrm{KA} 5-\mathrm{B}^{\mathrm{T}}$, was isolated from agricultural soil using the following procedures. A soil sample was collected from a vegetable cropping field located in Fukuoka prefecture, Japan. Agar was dissolved in distilled water and sterilized. The soil sample was added to the agar to a final concentration of $1.0 \%(\mathrm{w} / \mathrm{w}$, agar/dry soil). The water content was adjusted to $50 \%$ (w/w, water/dry soil). Agar-supplemented soil was packed in bottles and incubated at $28^{\circ} \mathrm{C}$ for $14 \mathrm{~d}$ to enrich agar-degrading bacteria. The soil samples were then suspended in $10 \mathrm{mM}$ phosphate buffer solution ( $\mathrm{pH} 7.0)$ and serially diluted. One hundred $\mu \mathrm{L}$ of the diluted portions were spread on PSG medium $\left(1.7 \mathrm{~g} \mathrm{~L}^{-1}\right.$ peptone, $0.3 \mathrm{~g} \mathrm{~L}^{-1}$ soytone, $0.25 \mathrm{~g} \mathrm{~L}^{-1}$ glucose, $0.25 \mathrm{~g} \mathrm{~L}^{-1} \mathrm{~K}_{2} \mathrm{HPO}_{4}$, and $0.5 \mathrm{~g} \mathrm{~L}^{-1} \mathrm{NaCl}$ ) solidified with $1.5 \%$ agar. After being incubated at $30^{\circ} \mathrm{C}$ for $10 \mathrm{~d}$, agar-degrading bacteria in colonies with depressed circumferences 
were selected and streaking was repeated on PSG agar to isolate pure colonies.

\section{Culture conditions and isolation of agar-degrading bacteria}

Two different morphologies were still observed by microscopy after streaking was repeating and the selected colonies were incubated in PSG liquid. These cells were designated strain KA5-A and strain KA5-B $\mathrm{B}^{\mathrm{T}}$. Streaking on plates and serial dilutions (1:10) failed to isolate the agar-degrading bacterium, and only strain KA5-A formed pure colonies on the PSG agar; however, it had no agardegrading ability. In contrast to KA5-A, no pure colonies of strain KA5- $\mathrm{B}^{\mathrm{T}}$ were detected on the agar plates. However, pure colonies of strain $\mathrm{KA} 5-\mathrm{B}^{\mathrm{T}}$ were detected on the agar plates after a 5-d incubation at $30^{\circ} \mathrm{C}$ when supernatants from KA5-A cultures were supplemented into the PSG medium, and these formations had depressed circumferences. Since the growth of strain KA5-B ${ }^{\mathrm{T}}$ was extremely poor, and a faint colony only formed on plates inoculated with a high density of the cells. The cells of strain KA5- ${ }^{\mathrm{T}}$, which were cultured at $30^{\circ} \mathrm{C}$ for $5 \mathrm{~d}$ with PSGS medium, solidified with agar containing $10 \%$ of the supernatant of the KA5-A culture by PSG liquid or cultured in PSGS liquid at $30^{\circ} \mathrm{C}$ until the beginning of the stationary phase, were used in the following analyses unless otherwise stated. When it was desirable to avoid the formation of a depressed circumference on the PSGS agar, strain KA5- $\mathrm{B}^{\mathrm{T}}$ was grown on media solidified with $1.5 \%(\mathrm{w} / \mathrm{v})$ gellan gum.

\section{Sequencing of the 16S rRNA gene and phylogenetic analysis}

The 16S rRNA gene sequencing of strains KA5-A and KA5- $\mathrm{B}^{\mathrm{T}}$ was conducted by PCR using two oligonucleotide primers, 5'AGAGTTTGATCCTGGCTCAG-3' and 5'-AAGGAGGTGATCC AGCC-3' (corresponding to positions 8-27 and 1525-1541 of the Escherichia coli 16S rRNA gene) (45). The genomic DNA of these strains was extracted according to the method described by Pitcher et al. (30). The amplified 16S rRNA gene was purified with a Qiaquick PCR purification kit (Qiagen) according to the manufacturer's instructions. The 16S rRNA genes were sequenced directly with a DNA Sequencer using flanking and internal primers. The resultant sequence was used for an initial homology search against sequences in GeneBank using the BLAST program.

Multiple alignments of the KA5- $\mathrm{B}^{\mathrm{T}}$ sequences were performed with its closest relatives using CLUSTAL W software (41). Phylogenetic trees were constructed by three different methods; neighbor-joining (32), maximum-likelihood (9), and maximumparsimony (11) algorithms using MEGA software version 5.1 (38) for all analyses. To evaluate the topology of the resultant tree, bootstrap analysis (10) was based on 1,000 resamplings.

\section{Examination of the commensal interaction that enhanced growth}

Seventeen bacteria including strain KA5-A were employed to examine the commensal interaction that enhanced the growth of strain KA5- $\mathrm{B}^{\mathrm{T}}$. The remaining sixteen bacteria were Arthrobacter nicotianae NBRC 14234 and Streptomyces albus NBRC 13014 for Actinobacteria, Bacillus subtilis NBRC 13719 for Firmicutes, Azorhizobium caulinodans NBRC 14845, Bradyrhizobium japonicum USDA 110, Brevundimonas subvibrioides NBRC 16000 , Mesorhizobium loti MAFF 301724, Rhizobium leguminosarum NBRC 14778, Rhizobium meliloti MAFF 303039, Rhizobium radiobacter NBRC 15193, Rhizobium rhizogenes MAFF 301724 , Sinorhizobium fredii IFO 14780 and Sphingomonas pruni NBRC 15498 for Alphaproteobacteria, Ralstonia solanacearum MAFF 730101 for Beta-proteobacteria, and Escherichia coli DH5 $\alpha$ and Pseudomonas putida NBRC 14614 for Gammaproteobacteria.

The respective bacteria were cultured in LB liquid $\left(10 \mathrm{~g} \mathrm{~L}^{-1}\right.$ peptone, $5 \mathrm{~g} \mathrm{~L}^{-1}$ yeast extract, and $5 \mathrm{~g} \mathrm{~L}^{-1} \mathrm{NaCl}$; $\mathrm{pH} 7.2$ ) at $30^{\circ} \mathrm{C}$ for $5 \mathrm{~d}$ while shaking at $100 \mathrm{rpm}$ with the multi shaker MMS-200 (Tokyo Rikakikai, Tokyo, Japan). After the incubation, the supernatants of cultured bacteria were recovered by centrifuging at $8,000 \times g$ and $4^{\circ} \mathrm{C}$ to avoid the collection of cell pellets. They were passed through a membrane filter with $0.22 \mu \mathrm{m}$ pores to remove residual cells. Filter papers cut to $0.5 \mathrm{~cm} \times 2.5 \mathrm{~cm}$ in size were soaked in the cell-free supernatants and placed on the PSG gellan gum plate to prepare two lines in parallel. Strain KA5- $\mathrm{B}^{\mathrm{T}}$ was subsequently inoculated by streaking side to side between the papers and incubated at $30^{\circ} \mathrm{C}$ for $5 \mathrm{~d}$. The plates with filter papers soaked in the LB liquid and without filter papers were also prepared as controls.

\section{Examination of polysaccharide-degrading ability}

The degradation ability of strain KA5- $\mathrm{B}^{\mathrm{T}}$ was investigated using various polysaccharides. Arabinan, wheat arabinoxylan, galactomannan, xyloglucan, debranched arabinan, pectic galactan, larch arabinogalactan, and polygalacturonic acid (1.0 $\mathrm{g} \mathrm{L}^{-1}$ each), agar, starch, and dextrin (2.0 $\mathrm{g} \mathrm{L}^{-1}$ each), and carboxymethyl cellulose (CM-cellulose) and xylan (5.0 $\mathrm{g} \mathrm{L}^{-1}$ each) were individually dissolved in HMM medium $\left(0.125 \mathrm{~g} \mathrm{~L}^{-1} \mathrm{Na}_{2} \mathrm{HPO}_{4} \cdot 2 \mathrm{H}_{2} \mathrm{O}, 0.25 \mathrm{~g} \mathrm{~L}^{-1}\right.$ $\mathrm{Na}_{2} \mathrm{SO}_{4}, 0.32 \mathrm{~g} \mathrm{~L}^{-1} \mathrm{NH}_{4} \mathrm{Cl}, 0.18 \mathrm{~g} \mathrm{~L}^{-1} \mathrm{MgSO}_{4}, 0.0067 \mathrm{~g} \mathrm{~L}^{-1}$ $\mathrm{FeCl}_{3} \cdot 6 \mathrm{H}_{2} \mathrm{O}, 0.013 \mathrm{~g} \mathrm{~L}^{-1} \mathrm{CaCl}_{2} \cdot 2 \mathrm{H}_{2} \mathrm{O}$ ) solidified with $1.5 \%$ gellan gum. The cells of the strain cultured in liquid media were washed with $10 \mathrm{mM}$ sodium phosphate buffer ( $\mathrm{pH}$ 7.0) after collection by centrifugation and again suspended in sodium phosphate buffer.

Regarding the setup of the experiment, filter paper was soaked in the cell-free supernatants of strain KA5-A prepared using the same procedure as that described in the section on the commensal interaction and was then placed on the HMM gellan gum plate. The suspended cells of strain KA5- $\mathrm{B}^{\mathrm{T}}$ were inoculated on respective plates by streaking according to the long side of the filter paper and incubated at $30^{\circ} \mathrm{C}$ for $14 \mathrm{~d}$.

The degradations of agar, starch, and dextrin were detected using Lugol staining (31). Degradations of the other polysaccharides were detected using Congo red staining (37) followed by decolorization with $1.0 \mathrm{M} \mathrm{NaCl}$ solution. Degradation abilities using both staining methods were confirmed by the appearance of a clear zone surrounding the KA5- $\mathrm{B}^{\mathrm{T}}$ colony.

\section{Macroscopic and microscopic observations}

Routine observations were performed to morphologically characterize strain $\mathrm{KA} 5-\mathrm{B}^{\mathrm{T}}$. The features of the colonies were investigated after they were incubated on gellan gum plates. Gram-staining, motility, morphology, cell size, and spore formation were examined with the cells cultured on the gellan gum plate and liquid medium using a phase-contrast microscope (Olympus, Tokyo, Japan) and scanning electron microscope (SEM) (Japan Electron Optics Laboratory, Tokyo, Japan). Gram-staining was conducted after cells were stained according to Hucker's method (27). Cultured cells that reached the death phase were also used to assess spore formation. Regarding the observation by the scanning electron microscopy, cells were washed with $10 \mathrm{mM}$ phosphate buffer solution (pH 7.0) and collected on the nucleopore filter. After freeze-drying, cells were vapor-coated with carbon and examined under the high vacuum mode at $5 \mathrm{kV}$.

\section{Physiological analysis}

The growth ranges of strain $\mathrm{KA} 5-\mathrm{B}^{\mathrm{T}}$ were investigated using cells grown on the gellan gum plate or liquid culture. Temperature ranges were investigated on gellan gum plates incubated at $10^{\circ} \mathrm{C}$, $15^{\circ} \mathrm{C}, 20^{\circ} \mathrm{C}, 30^{\circ} \mathrm{C}, 35^{\circ} \mathrm{C}, 37^{\circ} \mathrm{C}$, and $42^{\circ} \mathrm{C}$. The $\mathrm{pH}$ ranges and $\mathrm{NaCl}$ concentrations were investigated in the liquid culture. The $\mathrm{pH}$ was prepared from 4.0 to 10.0 at intervals of 0.5 and the $\mathrm{NaCl}$ concentrations used were $0 \%, 1 \%, 2 \%$, and $3 \%$. The optimal temperature, $\mathrm{pH}$, and $\mathrm{NaCl}$ concentration were also investigated simultaneously. Gellan gum plates inoculated with the strain was packed in an AnaeroPouch bag (Mitsubishi Gas Chemical Company, Tokyo, Japan) and incubated under anaerobic conditions for the anaerobic growth test.

Cytochrome oxidase and catalase activities and Gram-staining were investigated using cells grown on gellan gum plates that were incubated for $5 \mathrm{~d}$. Cytochrome oxidase activity was detected by the method using oxidase-testing paper (Nissui Pharmaceutical, Tokyo, 
Japan). Catalase activity was observed as the formation of bubbles in a $3 \% \mathrm{H}_{2} \mathrm{O}_{2}$ solution.

\section{Chemotaxonomic analysis}

Cells cultured in liquid medium were used to establish whole-cell fatty acid profiles, analyses of the main quinones, and the $\mathrm{G}+\mathrm{C}$ content mol (\%) of genomic DNA. Quinones and whole-cell fatty acids were extracted with chloroform/methanol $(2: 1, \mathrm{v} / \mathrm{v})$ and purified using the method described by Hiraishi et al. (14). After the purification, whole-cell fatty acids and quinones were analyzed using the GC-based Microbial Identification System (MIDI, Newark NJ, USA) and Shimadzu LC-10 HPLC system (Shimadzu, Kyoto, Japan), respectively. The $\mathrm{G}+\mathrm{C}$ content $(\mathrm{mol} \%)$ of DNA was determined by HPLC (18). Bacterial DNA was extracted using the same protocol as that described for genomic DNA extraction and digested with nuclease according to the manufacturer's instructions (Yamasa, Choshi, Japan).

\section{Examination of substrate oxidation}

Biolog GN2 microplates (Biolog, Hayward, CA, USA) were used in the absence of culture supernatant from companions to test the oxidation of various carbon sources. KA5- $\mathrm{B}^{\mathrm{T}}$ cells were cultured in liquid medium and washed with $10 \mathrm{mM}$ sodium phosphate buffer ( $\mathrm{pH}$ 7.0). Portions of cell suspensions were dispensed and incubated. Visual observations were performed after the incubation according to the manufacturer's instructions.

\section{Nucleotide sequence accession number}

The sequences obtained in this study were uploaded and are available on the DNA Data Banks under the accession numbers; AB300444 for KA5-A and AB174844 for KA5-B ${ }^{\mathrm{T}}$.

\section{Results and Discussion}

\section{Phylogenetic affiliation of strain KA5-A}

To investigate the phylogenetic affiliation of strain KA5A, which was obtained as a companion bacterium when strain KA5- $\mathrm{B}^{\mathrm{T}}$ was isolated, the $16 \mathrm{~S}$ rRNA gene of strain KA5-A was partially sequenced (corresponding to position 28-1524 of the Escherichia coli $16 \mathrm{~S}$ rRNA gene), and the obtained sequence showed $99.2 \%$ and $99.0 \%$ similarities with Mesorhizobium tamadayense (FN563430) (23) and Mesorhizobium tianshanense (JN685304) (unpublished data). Based on its phylogenetic composition, the strain was regarded as a member of the genus Mesorhizobium (Mesorhizobium sp. strain KA5-A).

\section{Commensal interaction that enhanced growth and polysaccharide-degrading ability}

The companion bacterium KA5-A is a member of the genus Mesorhizobium, which belongs to the order Rhizobiales in Alphaproteobacteria; therefore, we investigated the phylogenetic range needed to achieve growth enhancements in strain KA5- $\mathrm{B}^{\mathrm{T}}$ with the production of metabolite(s).

As shown in Fig. 1, a growth enhancement was observed in strain $\mathrm{KA} 5-\mathrm{B}^{\mathrm{T}}$ on the plate with filter papers containing the cell-free supernatants derived from strain KA5-A (Fig. 1a). However, KA5-B ${ }^{T}$ did not grow well without filter paper (Fig. 1b). Weak growth was only observed at locations inoculated with a high density of cells. Growth enhancements in strain KA5-B $\mathrm{B}^{\mathrm{T}}$ were also detected in all six bacteria tested that belonged to the order Rhizobiales, but were not in the two species, Brevundimonas subvibrioides NBRC 16000 and

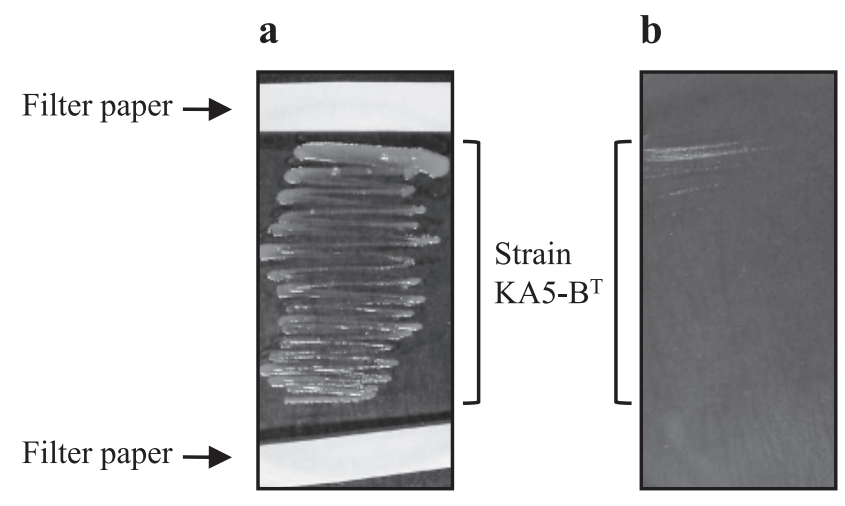

Fig. 1. Examination of the commensal interaction that enhanced the growth of strain KA5- $\mathrm{B}^{\mathrm{T}}$ by cell-free supernatants of the companions. The filter paper in Fig. 1a contained cell-free supernatants of strain KA5-A. The plate without filter paper was also prepared as a control (Fig. 1b).

Sphingomonas pruni NBRC 15498 in Alphaproteobacteria, and the other genera.

The polysaccharide-degrading ability of strain KA5- $\mathrm{B}^{\mathrm{T}}$ was investigated using various polysaccharides. Clear zones surrounded the KA5- $\mathrm{B}^{\mathrm{T}}$ colony after the 14-d incubation in all polysaccharides tested, which were agar, arabinan, CMcellulose, debranched arabinan, dextrin, galactomannan, larch arabinogalactan, pectic galactan, polygalacturonic acid, starch, wheat arabinoxylan, xylan, and xyloglucan.

These results indicated that the bacteria producing diffusible compounds that enhanced the growth of strain KA5-B were members of Rhizobiales. Tanaka et al. (39) isolated the novel bacterium Catellibacterium nectariphilum from activated sludge, and reported that this bacterium required diffusible metabolite(s) from a strain related to the genus Sphingomonas to enhance growth. A later study by Tanaka et al. (40) showed that the diffusible metabolite(s) were heat-stable, non-peptides with a low molecular weight (below $1,000 \mathrm{Da})$ produced by Sphingomonas adhaesiva. The KA5$\mathrm{B}^{\mathrm{T}}$ is possibly explained that growth of the strain was induced by the diffusible metabolite(s) from the bacteria of Rhizobiales, and the strain decomposed various polysaccharides derived from plants for anything that appeared to beneficial contribution for the bacteria of Rhizobiales. The identification of metabolite(s) may be important in order to more clearly elucidate bacterial interactions and establish a cultivation method for uncultivable bacteria that require metabolite(s) produced by other bacteria.

\section{Phylogenetic affiliation of strain $K A 5-B^{T}$ and its closest relatives}

The homology search results for the almost complete $16 \mathrm{~S}$ rRNA gene sequence $(1,493 \mathrm{bp})$ of strain KA5-B $\mathrm{B}^{\mathrm{T}}$ showed that the taxonomic status of the obtained sequence belonged to Gammaproteobacteria. The most closely affiliated bacteria of strain KA5-B ${ }^{\mathrm{T}}$ were Bacterium D29 (FJ654261) (unpublished data), Steroidobacter sp. ZUMI 137 (AB548216) (unpublished data), and Steroidobacter denitrificans FS $^{\mathrm{T}}$ (EF605262) (8) with 98.5\%, 96.8\%, and 96.5\% similarities, respectively.

The phylogenetic analysis shown in Fig. 2 indicated that strain KA5-B ${ }^{\mathrm{T}}$ belonged to the family Sinobacteraceae in 


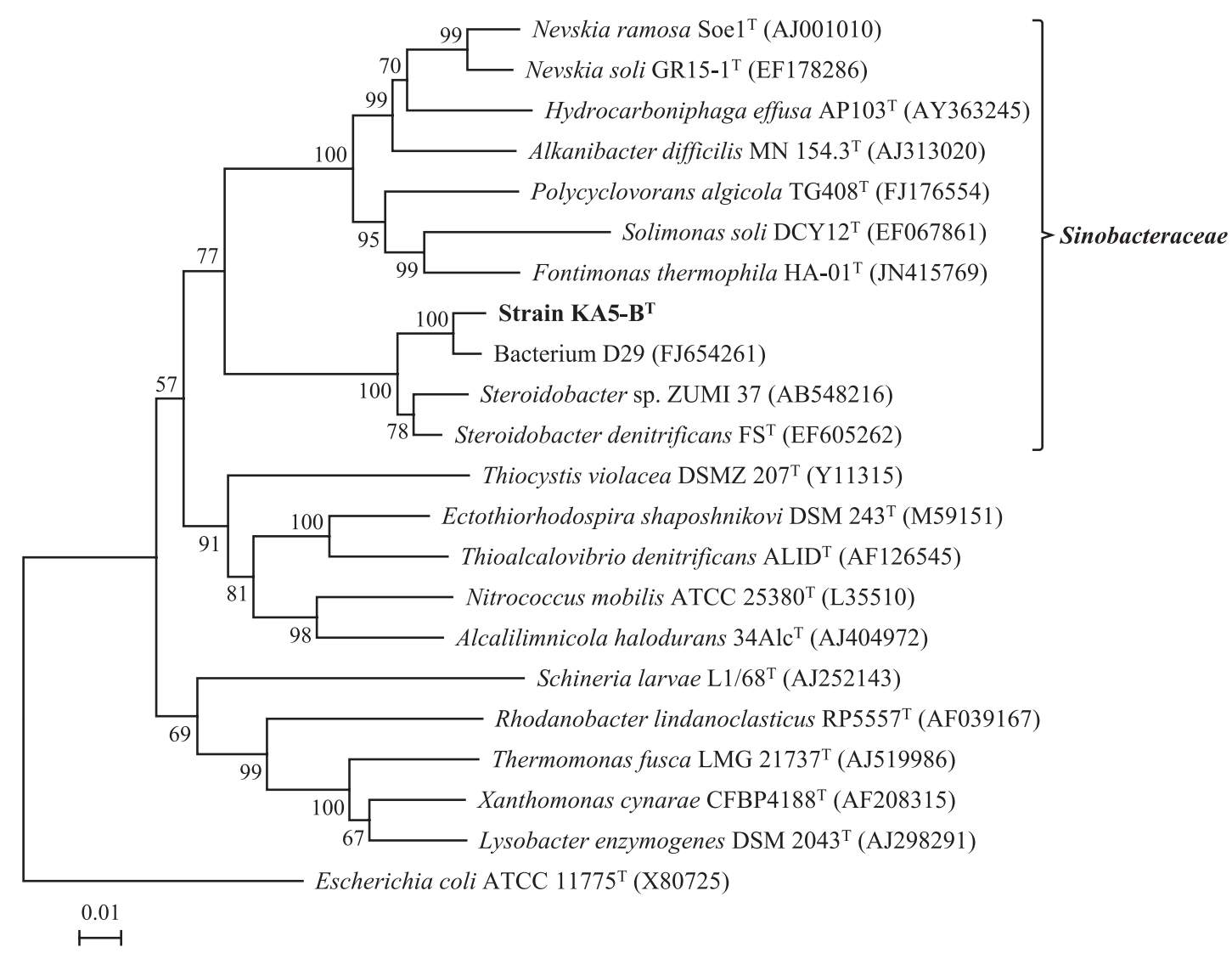

Fig. 2. Neighbor-joining phylogenetic tree based on $16 \mathrm{~S}$ rRNA gene sequence comparisons, showing the position of strain KA5-B ${ }^{\mathrm{T}}$ and its closest relatives within the class Gammaproteobacteria. Accession numbers for the sequences retrieved from the databases are given in parentheses. Bootstrap percentages at each node indicate the occurrence in 1,000 bootstrapped trees. The trees based on the maximum-parsimony and maximumlikelihood methods were almost identical to that obtained with the neighbor-joining method. Bar, 0.01 substitutions per nucleotide position.

Gammaproteobacteria. Genera Alkanibacter, Fontimonas, Hydrocarboniphaga, Nevskia, Polycyclovorans and Solimonas, which are members of the Sinobacteraceae family, were also closely related to strain KA5- $\mathrm{B}^{\mathrm{T}}$. However, this strain differed from any species in these genera with the following similarities; Alkanibacter difficilis MN154.3 ${ }^{\mathrm{T}}$ (AJ313020) for $87.6 \%$, Fontimonas thermophila HA-01 ${ }^{\mathrm{T}}$ (LN415769) for $87.2 \%$, Hydrocarboniphaga effusa AP103 ${ }^{\mathrm{T}}$ (AY363245) for $87.4 \%$, Nevskia ramosa Soe1 ${ }^{\mathrm{T}}$ (AJ001010) for 87.1\%, Nevskia soli GR15-1 ${ }^{\mathrm{T}}$ (EF178286) for 86.9\%, Polycyclovorans algicola TG408 ${ }^{\mathrm{T}}$ (FJ176554) for $86.3 \%$, and Solimonas soli DCY12 ${ }^{\mathrm{T}}$ (EF067861) for 87.6\%, which indicated that strain $\mathrm{KA} 5-\mathrm{B}^{\mathrm{T}}$ belonged to a different genus to these genera.

On the other hand, strain KA5-B ${ }^{\mathrm{T}}$ showed $96.5 \%$ similarity with Steroidobacter denitrificans $\mathrm{FS}^{\mathrm{T}}$, which is the sole species in the genus Steroidobacter. However, this strain formed a different cluster from Steroidobacter denitrificans $\mathrm{FS}^{\mathrm{T}}$ in the phylogenetic tree (Fig. 2), and showed the highest affiliation with Bacterium D29, which indicated that strain $\mathrm{KA} 5-\mathrm{B}^{\mathrm{T}}$ is a novel species in the genus Steroidobacter. The similarity value of the $16 \mathrm{~S}$ rRNA gene sequence is known to play an important role in delineating novel taxa and identifying isolates (6). Stackebrandt and Goebel (33) suggested that a $16 \mathrm{~S}$ rRNA gene sequence similarity of $97 \%$ should become the boundary of delineation of prokaryotic species, which has been well accepted among microbiologists.
Stackebrandt and Ebers (34) later proposed a more relaxed cutoff of $98.7-99 \%$, after inspecting a large number of recently published studies. Logan et al. (22) and Tindall et al. (42) also reported that DNA-DNA hybridization, which has been employed to identify new species within a taxon, was optional for new taxa encompassing a single strain that shared more than 97\% $16 \mathrm{~S}$ rRNA gene sequence similarity to its closest neighbor. Due to these reasons, DNA-DNA hybridization was not performed between strain $\mathrm{KA} 5-\mathrm{B}^{\mathrm{T}}$ and Steroidobacter denitrificans $\mathrm{FS}^{\mathrm{T}}$ because of the similarity level of $96.5 \%$, and the strain was regarded as a new species at the phylogenetic level.

\section{Morphological and physiological characteristics}

The morphological and physiological characteristics of strain KA5- $\mathrm{B}^{\mathrm{T}}$ were investigated and the results were compiled in Table 1. The strain formed smooth, circular, paleyellow colonies on gellan gum plates. Gram-staining, motility, and cell size and shape were examined using phasecontrast microscopy and scanning electron microscopy (Fig. 3a). The cells of strain $\mathrm{KA} 5-\mathrm{B}^{\mathrm{T}}$ were Gram-negative, non-motile, had a straight to slightly curved rod shape, and were $0.4-0.6 \mu \mathrm{m}$ in width by $1.0-2.1 \mu \mathrm{m}$ in length. These cells were included in a fibrous polysaccharide matrix when cultivated in liquid medium (Fig. 3b). Spore formation was not observed.

The physiological analysis revealed that visible colonies 
Table 1. Phylogenetic characteristics of strain KA5- $\mathrm{B}^{\mathrm{T}}$ in comparison with its closest relatives. The data of its closest relatives were compiled from Fahrbach et al. (8), Friedrich and Lipski (12), Losey et al. (24), Palleroni et al. (29), Stürmeyer et al. (36), Gutierrez et al. (13), Kim et al. (19) for Steroidobacter denitrificans, Alkanibacter difficilis, Fontimonas thermophilia, Hydrocarboniphaga effusa, Nevskia ramosa, Polycyclovorans algicola and Solimonas soli, respectively. The data of Weon et al. (44), Kim et al. (20), Babenzien and Cypionka (2), and Cypionka et al. (7) were also used as related references. All bacteria were Gram-negative and non-spore forming. Sum3 and 8 were composed of iso- $\mathrm{C}_{15: 0} 2-\mathrm{OH}, \mathrm{C}_{16: 1} \omega 7 \mathrm{c}$ and $\mathrm{C}_{18: 1} \omega 9 \mathrm{c}$, and $\mathrm{C}_{18: 1} \omega 9 \mathrm{c}, \mathrm{C}_{18: 1} \omega 7 \mathrm{c}$, and $\mathrm{C}_{18: 1} \omega 6 \mathrm{c}$, respectively. The symbols, ,+- and \pm , indicate positive, negative, and weakly positive, respectively. ND indicates "not determined" or "no data available".

\begin{tabular}{|c|c|c|c|c|c|c|c|c|}
\hline & $\begin{array}{c}\text { Strain } \\
\text { KA5-B }\end{array}$ & $\begin{array}{c}\text { Steroidobacter } \\
\text { denitrificans }\end{array}$ & $\begin{array}{l}\text { Alkanibacter } \\
\text { difficilis }\end{array}$ & $\begin{array}{l}\text { Fontimonas } \\
\text { thermophila }\end{array}$ & $\begin{array}{c}\text { Hydrocarboniphaga } \\
\text { effusa }\end{array}$ & $\begin{array}{l}\text { Nevskia } \\
\text { ramosa }\end{array}$ & $\begin{array}{l}\text { Polycyclovorans } \\
\text { algicola }\end{array}$ & $\begin{array}{l}\text { Solimonas } \\
\quad \text { soli }\end{array}$ \\
\hline $\begin{array}{l}\text { Similarity (\%) to } \\
\text { the } 16 \mathrm{~S} \text { rRNA } \\
\text { gene }\end{array}$ & & 96.5 & 87.6 & 87.2 & 87.4 & 87.1 & 86.5 & 87.6 \\
\hline $\begin{array}{l}\text { Cell size width } \\
\text { by length }(\mu \mathrm{m})\end{array}$ & $\begin{array}{c}0.4-0.6 \text { by } \\
1.0-2.1\end{array}$ & $\begin{array}{c}0.3-0.5 \text { by } \\
0.6-1.6\end{array}$ & $\begin{array}{c}0.5-0.7 \text { by } \\
0.6-1.2\end{array}$ & $\begin{array}{c}0.5-0.75 \text { by } \\
1.0-2.0\end{array}$ & $\begin{array}{c}0.75-0.85 \text { by } \\
1.5-2.0\end{array}$ & $\begin{array}{c}0.7-1.1 \text { by } \\
1.5-2.3\end{array}$ & $\begin{array}{l}0.5 \text { by } \\
1.0-1.2\end{array}$ & $\begin{array}{c}0.2-0.4 \text { by } \\
0.3-0.5\end{array}$ \\
\hline Cell morphology & $\begin{array}{l}\text { straight to slightly } \\
\text { curved rod }\end{array}$ & $\begin{array}{l}\text { slightly } \\
\text { curved rod }\end{array}$ & small rod & rod & rod & $\begin{array}{l}\text { slightly } \\
\text { curved rod }\end{array}$ & rod & rod \\
\hline Motility & non-motile & $\begin{array}{l}\text { motile by single } \\
\text { polar flagellum }\end{array}$ & ND & $\begin{array}{l}\text { motile by single } \\
\text { polar flagellum }\end{array}$ & $\begin{array}{l}\text { motile by single } \\
\text { flagellum of } \\
\text { polar, subpolar } \\
\text { or insertion }\end{array}$ & $\begin{array}{l}\text { motile by single } \\
\text { polar flagellum }\end{array}$ & $\begin{array}{l}\text { motile by single } \\
\text { polar flagellum }\end{array}$ & non-motile \\
\hline $\begin{array}{l}\mathrm{G}+\mathrm{C} \text { content } \\
(\mathrm{mol} \%)\end{array}$ & 62.9 & 61.9 & 62.8 & 64.4 & $60-61$ & 67.8 & 64.3 & 40.5 \\
\hline Catalase & + & + & + & + & + & \pm & + & + \\
\hline Oxydase & + & + & + & + & + & + & + & + \\
\hline Main quinone & Q-8 & Q-8 & Q-8 & Q-8 & ND & ND & Q-8 & Q-8 \\
\hline $\begin{array}{l}\text { Main fatty acids } \\
(\geq 10 \%)\end{array}$ & $\begin{array}{c}\text { iso- } \mathrm{C}_{15: 0}, \\
\mathrm{C}_{16: 1} \omega 7 \mathrm{c}, \\
\text { iso- }_{177: 1} \omega 9 \mathrm{c}\end{array}$ & $\mathrm{C}_{15: 0}, \mathrm{C}_{17: 1} \omega 8 \mathrm{c}$ & $\begin{array}{c}\mathrm{C}_{16: 0}, \mathrm{C}_{18: 0}, \\
\mathrm{C}_{18: \mathrm{c}} \mathrm{c} \text { cis11, } \\
\mathrm{C}_{19: 0 \mathrm{o}} \text { cyclo11-12 }\end{array}$ & $\begin{array}{c}\text { Iso- } \mathrm{C}_{16: 0}, \mathrm{C}_{16: 1} \omega 5 \mathrm{c}, \\
\text { sum } 8\end{array}$ & $\begin{array}{l}\mathrm{C}_{12: 0}, \mathrm{C}_{16: 0}, \\
\mathrm{C}_{16: 1} \mathrm{cis} 9, \\
\mathrm{C}_{18: 1} \mathrm{cis} 11\end{array}$ & $\begin{array}{c}\mathrm{C}_{14: 0}, \mathrm{C}_{18: 1}(\omega 7 \mathrm{c} \\
\text { sum3 }\end{array}$ & $\begin{array}{c}\mathrm{C}_{16: 0}, \mathrm{C}_{16: 1} \omega 7 \mathrm{c} \\
\mathrm{C}_{18: 1} \omega 7 \mathrm{c}\end{array}$ & $\begin{array}{l}\mathrm{C}_{16: 0}, \mathrm{C}_{18: 0}, \\
\quad \text { sum3 }\end{array}$ \\
\hline $\begin{array}{l}\text { Growth on an agar } \\
\text { plate }\end{array}$ & + & - & + & + & + & + & + & + \\
\hline Anaerobic growth & - & + & - & - & - & - & - & + \\
\hline Growth at $15^{\circ} \mathrm{C}$ & + & - & - & - & + & + & + & - \\
\hline Growth at $\mathrm{pH} 5.0$ & + & - & ND & - & ND & ND & - & - \\
\hline \multicolumn{9}{|l|}{ Utilization of: } \\
\hline Acetate & - & + & - & - & $\pm /-$ & + & + & + \\
\hline Citrate & - & - & - & - & ND & ND & ND & - \\
\hline Galactose & + & - & - & - & - & ND & ND & ND \\
\hline D-Glucose & + & - & - & - & - & + & ND & + \\
\hline Glutamate & \pm & + & - & $\pm /-$ & + & + & \pm & ND \\
\hline Lactose & + & - & - & - & + & + & ND & - \\
\hline Propionate & - & + & - & - & + & - & + & \pm \\
\hline Sucrose & + & - & - & - & $+/ \pm$ & $+/-$ & ND & - \\
\hline
\end{tabular}

were detectable at $15-37^{\circ} \mathrm{C}$, with optimum growth being observed at $30^{\circ} \mathrm{C}$ on gellan gum plates. No growth occurred at $10^{\circ} \mathrm{C}$ or $42^{\circ} \mathrm{C}$. In addition, the strain was able to grow in liquid medium between $\mathrm{pH} 4.5$ and 9.0 with optimum growth at $\mathrm{pH}$ 6.0-8.0. No growth was observed when $3 \%(\mathrm{w} / \mathrm{v}) \mathrm{NaCl}$ was added to the liquid medium, while the strain grew at $\mathrm{NaCl}$ concentrations of $0 \%, 1 \%$, and $2 \%$. Metabolism was strictly aerobic and no growth occurred under anaerobic conditions. Cytochrome oxidase and catalase showed positive reactions, respectively.

\section{Chemotaxonomic characteristics}

Whole-cell fatty acids, the main quinones, and $\mathrm{G}+\mathrm{C}$ content $(\mathrm{mol} \%)$ were analyzed after the extraction and purification of the respective targeted matter from the cells of strain $\mathrm{KA} 5-\mathrm{B}^{\mathrm{T}}$. Whole-cell fatty acid profiles for $\mathrm{KA} 5-\mathrm{B}^{\mathrm{T}}$ were dominated by $\mathrm{C}_{16: 1} \omega 7 \mathrm{c}(32.1 \%)$, iso- $\mathrm{C}_{15: 0}(18.1 \%)$, iso$\mathrm{C}_{17: 1} \omega 9 \mathrm{c}(11.8 \%), \mathrm{C}_{16: 0}(8.7 \%)$, and iso- $\mathrm{C}_{17: 0}(7.9 \%)$. Other cellular fatty acids that were present at levels greater than $1 \%$ included iso- $\mathrm{C}_{16: 0}(5.6 \%), \mathrm{C}_{12: 0}(4.7 \%), \mathrm{C}_{12: 0} 3-\mathrm{OH}(4.6 \%)$, iso- $\mathrm{C}_{11: 0}(3.9 \%)$, and $\mathrm{C}_{12: 0} 2-\mathrm{OH}(2.7 \%)$. The composition of respiratory quinones indicated that ubiquinone-8 (Q-8) was predominant. The $\mathrm{G}+\mathrm{C}$ content of genomic DNA was 62.9 mol\% (HPLC).

\section{Oxidation of substrates}

In the oxidation test on various carbon sources in Biolog GN2 microplates, strain KA5- $\mathrm{B}^{\mathrm{T}}$ oxidized the following substrates; dextrin, tween 40, L-arabinose, cellobiose, Dgalactose, gentiobiose, $\alpha-\mathrm{D}-$ glucose, $\alpha-\mathrm{D}-$ lactose, $\mathrm{D}-$ melibiose, $\beta$-methyl-D-glucoside, L-raffinose, sucrose, and $\alpha-$ ketoglutaric acid. The oxidation of D-fructose, lactulose, maltose, L-rhamnose, D-trehalose, turanose, methyl pyruvate, DL-lactic acid, alaninamide, L-alanine, L-glutamic acid, hydroxy-L-proline, L-proline, L-threonine, and glucose 6-phosphate was weakly positive. The oxidation of the other organic substrates including acetate and citrate was negative. 

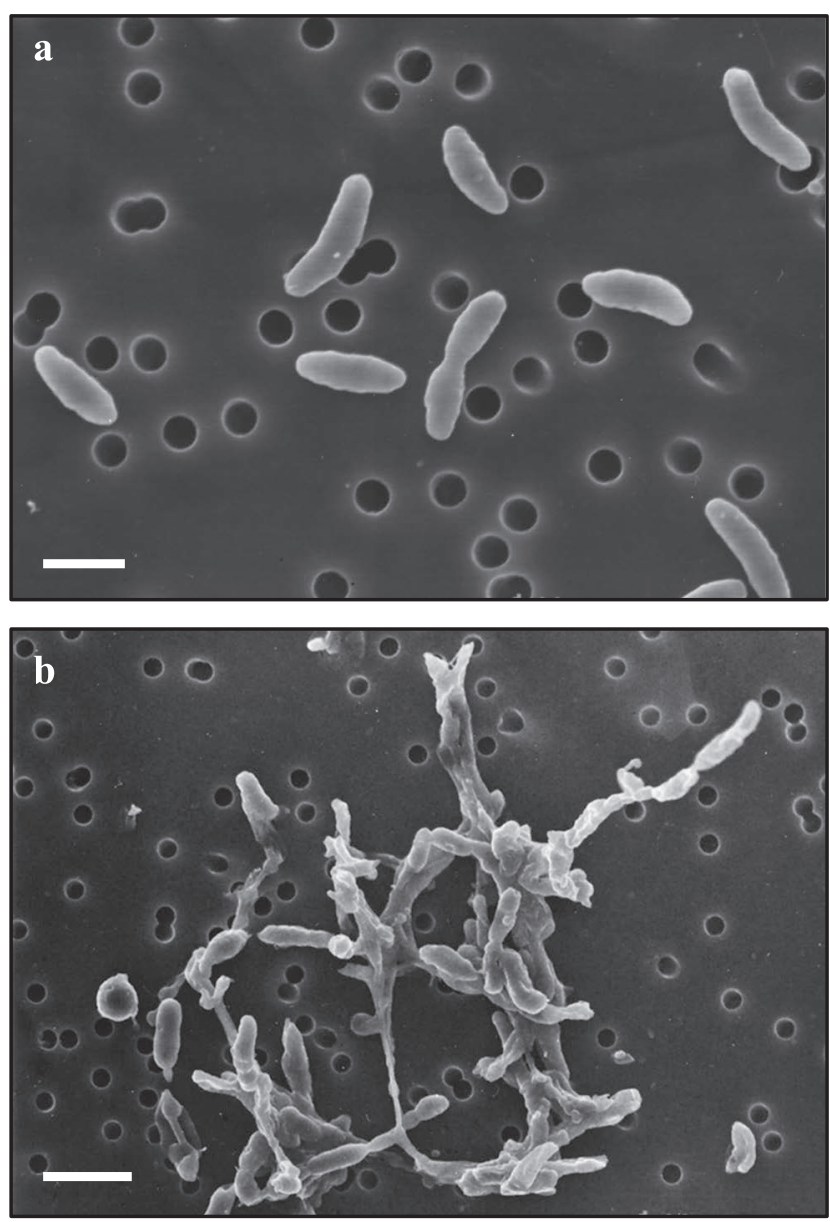

Fig. 3. Scanning electron micrographs of strain $\mathrm{KA} 5-\mathrm{B}^{\mathrm{T}}$ grown on $1.5 \%$ gellan gum plate (a) and in liquid culture (b). Bars, (a) $1 \mu \mathrm{m}$ and (b) $2 \mu \mathrm{m}$.

\section{Morphological and phenotypic comparisons among strain $K A 5-B^{T}$ and its closest relatives}

Table 1 shows the morphological and phenotypic characteristics of strain KA5- $\mathrm{B}^{\mathrm{T}}$ and the type species of its closest relatives in the Sinobacteraceae family. In addition to a high sequence divergence, the closest relatives possessed different morphological and physiological characteristics. The major fatty acids were used as the predominant feature to distinguish species from each other. Compared to Steroidobacter denitrificans $\mathrm{FS}^{\mathrm{T}}$, strain $\mathrm{KA} 5-\mathrm{B}^{\mathrm{T}}$ was non-motile, strictly aerobic, and it grew on agar plates at $15^{\circ} \mathrm{C}$ and $\mathrm{pH}$ 5.0. The utilization of lactose, galactose, D-glucose, and sucrose was positive and glutamate was weakly positive, while acetate and propionate were negative. In contrast, Steroidobacter denitrificans $\mathrm{FS}^{\mathrm{T}}$ was motile, grew anaerobically, and did not grow on agar plates at $15^{\circ} \mathrm{C}$ and $\mathrm{pH}$ 5.0. The utilization of acetate, glutamate, and propionate were positive, while lactose, galactose, D-glucose, and sucrose were negative.

Thus, strain KA5- $\mathrm{B}^{\mathrm{T}}$ showed distinguishable features from Steroidobacter denitrificans $\mathrm{FS}^{\mathrm{T}}$ at the morphological and physiological levels, which indicated that KA5-B is a novel species in the genus Steroidobacter. Based on the above results, we propose that strain $\mathrm{KA} 5-\mathrm{B}^{\mathrm{T}}$ belongs to a novel species, for which the name Steroidobacter agariperforans sp. nov. is proposed.
Description of Steroidobacter agariperforans $s p$. nov.

Steroidobacter agariperforans (a.ga.ri.per.fo'rans. Malayan n. agar agar; N.L. n. agarum agar [algal polysaccharide]; L. part. adj. perforans perforating [making holes]; N.L. part. adj. agariperforans making holes in agar, bacterium making deep hollows in agar).

It is Gram-negative, strictly aerobic, non-motile, oxidase and catalase positive, and does not form spores. Cells have a straight to slightly curved rod shape $(0.4-0.6 \mu \mathrm{m}$ in width by $1.0-2.1 \mu \mathrm{m}$ in length) and hydrolyze agar. Included in the fibrous polysaccharide matrix when cultivated in liquid medium. Diffusible metabolite(s) produced by bacteria in the order Rhizobiales may be required for vigorous growth. Colonies are circular and pale yellow in color. The temperature and $\mathrm{pH}$ ranges for growth are $15-37^{\circ} \mathrm{C}$ and between $\mathrm{pH} 4.5$ and 9.0, with optimum growth occurring at $30^{\circ} \mathrm{C}$ and pH $6.0-8.0$. No growth occurred at 10 or $42^{\circ} \mathrm{C}$ and $\mathrm{NaCl}$ concentrations more than $3 \%(\mathrm{w} / \mathrm{v})$. The main cellular fatty acids are $\mathrm{C}_{16: 1} \omega 7 \mathrm{c}(32.1 \%)$, iso- $\mathrm{C}_{15: 0}(18.1 \%)$, and iso$\mathrm{C}_{17: 1} \omega 9 \mathrm{c}(11.8 \%)$. Q- 8 is the main component of the quinone system. The DNA G+C content of the type strain of the type species is $62.9 \mathrm{~mol} \%$ (by HPLC). 16S rRNA gene sequence analysis places the genus in the class Gammaproteobacteria. According to Biolog GN2 tests, the type strain is positive for the oxidation of dextrin, tween 40, L-arabinose, cellobiose, $\mathrm{D}$-galactose, gentiobiose, $\alpha-\mathrm{D}$-glucose, $\alpha-\mathrm{D}$-lactose, Dmelibiose, $\beta$-methyl-D-glucoside, L-raffinose, sucrose and $\alpha$-ketoglutaric acid. The oxidation of D-fructose, lactulose, maltose, L-rhamnose, D-trehalose, turanose, methyl pyruvate, DL-lactic acid, alaninamide, L-alanine, L-glutamic acid, hydroxy-L-proline, L-proline, L-threonine, and glucose 6-phosphate was weakly positive. The oxidation of the other organic substrates including acetate and citrate in Biolog GN2 microplates was negative. The type strain is Steroidobacter agariperforans $\mathrm{KA} 5-\mathrm{B}^{\mathrm{T}}\left(\mathrm{JCM} 18477^{\mathrm{T}}=\right.$ KCTC $32107^{\mathrm{T}}$ ), which was isolated from a soil sample.

\section{Acknowledgements}

We appreciate our laboratory students at Kyushu and Kagoshima universities for assisting us in this ongoing study. Special thanks for Yuichiro Ando, a graduate student of Kagoshima University, for being involved in one part of the reexamination.

\section{References}

1. Agbo, J.A.C., and M.O. Moss. 1979. The isolation and characterization of agarolytic bacteria from a lowland river. J. Gen. Microbiol. 115:355-368.

2. Babenzien, H.D., and H. Cypionka. 2005. Genus V. Nevskia Famintzin $1892,484^{\mathrm{AL}}$ p. 101-104. In G.M. Garrity, D.J. Brenner, N.R. Krieg, and J. Staley. (ed.), Bergey's Manual of Systematic Bacteriology, the Proteobacteria, Part B the Gammaproteobacteria. Springer, New York.

3. Bacic, A., S.F. Moody, and A.E. Clarke. 1986. Structural analysis of secreted root slime from maize. Plant Physiol. 80:771-777.

4. Bannikova, G.E., S.A. Lopatin, V.P. Varlamov, B.B. Kuznetsov, I.V. Kozina, M.L. Miroshnichenko, N.A. Chernykh, T.P. Turova, and E.A. Bonch-Osmolovskaya. 2008. The thermophilic bacteria hydrolyzing agar: characterization of thermostable agarase. Appl. Biochem. Microbiol. 45:366-371.

5. Chaboud, A., and M. Rougier. 1984. Identification and localization of sugar components of rice (Oryza sativa L.) root cap mucilage. J. Plant Physiol. 116:323-330. 
6. Chun, J., J.H. Lee, Y. Jung, M. Kim, S. Kim, B.K. Kim, and Y.W. Lim. 2007. ExTaxon: a web-based tool for the identification of prokaryotes based on $16 \mathrm{~S}$ ribosomal RNA gene sequences. Int. J. Syst. Bacteriol. 57:2259-2261.

7. Cypionka, H., H.D. Babenzien, F.O. Glockner, and R. Amann 2006. The Genus Nevskia. p. 1152-1155. In M. Dworkin, S. Falkow, E. Rosenberg, K.H. Schleifer, and E. Stackebrabdt. (ed.), The prokaryotes, A Hand Book on the Biology of Bacteria: Proteobacteria: Gamma Subclass. Springer, New York.

8. Fahrbach, M., J. Kuever, M. Remesch, B.E. Huber, P. Kämpfer, W. Dott, and J. Hollender. 2008. Steroidobacter denitrificans gen. nov., sp. nov., a steroidal hormone-degrading gammaproteobacterium. Int. J. Syst. Evol. Microbiol. 58:2215-2223.

9. Felsenstein, J. 1981. Evolutionary trees from DNA sequences: a maximum likelihood approach. J. Mol. Evol. 17:368-376.

10. Felsenstein, J. 1985. Confidence limits on phylogenies: an approach using the bootstrap. Evolution 39:783-791.

11. Fitch, W.M. 1971. Toward defining the course of evolution: minimum change for a specific tree topology. Syst. Zool. 20:406-416.

12. Friedrich, M.M., and A. Lipski. 2008. Alkanibacter difficilis gen. nov., sp. nov. and Singularimonas variicoloris gen. nov., sp. nov., hexanedegrading bacteria isolated from a hexane-treated biofilter. Int. J. Syst. Evol. Microbiol. 58:2324-2329.

13. Gutierrez, T., D.H. Green, P.D. Nichols, W.B. Whitman, K.T. Semple, and M.D. Aitken. 2013. Polycyclovorans algicola gen nov., sp. nov., an aromatic-hydrocarbon-degrading marine bacterium found associated with laboratory cultures of marine phytoplankton. Appl. Environ. Microbiol. 79:205-214.

14. Hiraishi, A., K. Muramatsu, and Y. Ueda. 1996. Molecular genetic analyses of Rhodobacter azotoformans sp. nov. and related species of phototrophic bacteria. Syst. Appl. Microbiol. 19:168-177.

15. Hosoda, A., and M. Sakai. 2006. Isolation of Asticcacaulis sp. SA7, a novel agar-degrading Alphaproteobacterium. Biosci. Biotechnol. Biochem. 70:722-725.

16. Hosoda, A., M. Sakai, and S. Kanazawa. 2003. Isolation and characterization of agar-degrading Paenibacillus spp. associated with the rhizosphere of spinach. Biosci. Biotechnol. Biochem. 67:1048-1055.

17. Hunger, W., and D. Claus. 1978. Reisolation and growth conditions of Bacillus agar-exedens. Antonie van Leeuwenhoek 44:105-113.

18. Katayama-Fujimura, Y., Y. Komatsu, H. Kuraishi, and T. Kaneko. 1984. Estimation of DNA base composition by high performance liquid chromatography of its nuclease P1 hydrolysate. Agric. Biol. Chem. 48:3169-3172.

19. Kim, M.K., Y.J. Kim, D.H. Cho, T.H. Yi, N.K. Soung, and S.C. Yang. 2007. Solimonas soli gen nov., sp. nov., isolated from soil of a ginseng field. Int. J. Syst. Evol. Microbiol. 57:2591-2594.

20. Kim, S.J., H.Y. Weon, Y.S. Kim, I.C. Park, J.A. Son, and S.W. Kwon. 2011. Nevskia terrae sp. nov., isolated from soil. Int. J. Syst. Evol. Microbiol. 61:1226-1229.

21. Knee, E.M., F.C. Gong, M. Gao, M. Teplitski, A.R. Jones, A. Foxworthy, A.J. Mort, and W.D. Bauer. 2001. Root mucilage from pea and its utilization by rhizosphere bacteria as a sole carbon source. Mol. Plant Microbe Interact. 14:775-784.

22. Logan, N.A., O. Berge, A.J. Bishop, et al. 2009. Proposal minimal standards for describing new taxa of aerobic, endospore-forming bacteria. Int. J. Syst. Evol. Microbiol. 59:2114-2121.

23. Lorite, M.J., J. Donate-Correa, M. del Arco-Aguilar, G.R. Perez, J. Sanjuan, and M. Leon-Barrios. 2010. Lotus endemic to the Canary Islands are nodulated by diverse and novel rhizobial species and symbiotypes. Syst. Appl. Microbiol. 33:282-290.

24. Losey, N.A., B.S. Stevenson, S. Verbarg, S. Rudd, E.R.B. Moore, and P.A. Lawson. 2013. Fontimonas thermophilia, gen. nov., sp. nov., a moderately thermophilic bacterium isolated from a freshwater hot spring. Proposal of Solimonadaceae fam. nov. to replace Sinobacteraceae Zhou et al. 2008. Int. J. Syst. Evol. Microbiol. 63:254-259.

25. Miyazaki, M., Y. Nogi, Y. Ohta, Y. Hatada, Y. Fujiwara, S. Ito, and K. Horikoshi. 2008. Microbulbifer agarilyticus sp. nov. and Microbulbifer thermotolerans sp. nov., agar-degrading bacteria isolated from deep-sea sediment. Int. J. Syst. Evol. Microbiol. 58:1128-1133.

26. Moody, S.F., A.E. Clarke, and A. Bacic. 1988. Structural analysis of secreted slime from wheat and cowpea roots. Phytochemistry 27:2857-2861.
27. Murray, R.G.E., R.N. Doetsch, and C.F. Robinow. 1994. Determinative and cytological light microscopy. p. 32. In P. Gerhardt, R.G.E. Murray, W.A. Wood, and N.R. Krieg. (ed.), Methods for General and Molecular Bacteriology. American Society for Microbiology, Washington, D.C.

28. Ohta, Y., Y. Nogi, M. Miyazaki, Z. Li, Y. Hatada, S. Ito, and K. Horikoshi. 2004. Enzymatic properties and nucleotide and amino acid sequences of a thermostable $\beta$-agarase from the novel marine isolate, JAMB-A95. Biosci. Biotechnol. Biochem. 68:1073-1081.

29. Palleroni, N.J., A.M. Port, H.K. Chang, and G.J. Zylstra. 2004. Hydrocarboniphaga effusa gen. nov., sp. nov., a novel member of the $\gamma$-Proteobacteria active in alkane and aromatic hydrocarbon degradation. Int. J. Syst. Evol. Microbiol. 54:1203-1207.

30. Pitcher, D.G., N.A. Saunders, and R.J. Owen. 1989. Rapid extraction of bacterial genomic DNA with guanidium thiocyanate. Lett. Appl. Microbiol. 8:151-156.

31. Ruijssenaars, H.J., and S. Hartmans. 2001. Plate screening methods for the detection of polysaccharase-producing microorganisms. Appl. Microbiol. Biotechnol. 55:143-149.

32. Saitou, N., and M. Nei. 1987. The neighbor-joining method: a new method for reconstructing phylogenetic trees. Mol. Biol. Evol. 4:406-425.

33. Stackebrandt, E., and B.M. Goebel. 1994. Taxonomic note: a place for DNA-DNA reassociation and 16S rRNA sequence analysis in the present species definition in bacteriology. Int. J. Syst. Bacteriol. 44:846-849.

34. Stackebrandt, E., and J. Ebers. 2006. Taxonomic parameters revisited: tarnished gold standards. Microbiol. Today 33:152-155.

35. Stanier, R.Y. 1942. Agar-decomposing strains of the Actinomyces coelicolor species-group. J. Bacteriol. 44:555-570.

36. Stürmeyer, H., J. Overmann, H.D. Babenzien, and H. Cypionka. 1998. Ecophysiological and phylogenetic studies of Nevskia ramose in pure culture. Appl. Environ. Microbiol. 64:1890-1894.

37. Suyama, K., H. Yamamoto, T. Naganawa, T. Iwata, and H. Komada. 1993. A plate count method for aerobic cellulose decomposers in soil by congo red staining. Soil Sci. Plant Nutr. 39:361-365.

38. Tamura, K., D. Peterson, N. Peterson, G. Stecher, M. Nei, and S. Kumar. 2011. MEGA5: molecular evolutionary genetics analysis using maximum likelihood, evolutionary distance, and maximum, parsimony methods. Mol. Biol. Evol. 28:2731-2739.

39. Tanaka, Y., S. Hanada, A. Manome, T. Tsuchida, R. Kureane, K. Nakamura, and Y. Kamagata. 2004. Catellibacterium nectariphilum gen. nov., sp. nov., which requires a diffusible compound from a strain related to the genus Sphingomonas for vigorous growth. Int. J. Syst. Evol. Microbiol. 54:955-959.

40. Tanaka, Y., S. Hanada, H. Tamaki, K. Nakamura, and Y. Kamagata. 2005. Isolation and identification of bacterial strains producing diffusible growth factor(s) for Catellibacterium nectariphilum strain AST4T $^{\mathrm{T}}$. Microbes Environ. 20:110-116.

41. Thompson, J.D., D.G. Higgins, and T.J. Gibson. 1994. CLUSTAL W: improving the sensitivity of progressive multiple sequence alignment through sequence weighting, position-specific gap penalties and weight matrix choice. Nucleic Acids Res. 22:4673-4680.

42. Tindall, B.J., R. Rosselló-Móra, H.J. Busse, W. Ludwig, and P. Kämpfer. 2010. Notes on the characterization of prokaryote strains for taxonomic purposes. Int. J. Syst. Evol. Microbiol. 60:249-266.

43. van der Meulen, H.J., W. Harder, and H. Veldkamp. 1974. Isolation and characterization of Cytophaga flevensis sp. nov., a new agarolytic flexibacterium. Antonie van Leeuwenhoek 40:329-346.

44. Weon, H.Y., B.Y. Kim, J.A. Son, M.H. Song, S.W. Kwon, S.J. Go, and E. Stackebrandt. 2008. Nevskia soli sp. nov., isolated from soil cultivated with Korean ginseng. Int. J. Syst. Evol. Microbiol. 58:578-580.

45. Winker, S., and C.R. Woese. 1991. A definition of the domains Archaea, Bacteria and Eucarya in terms of small subunit ribosomal RNA characteristics. Syst. Appl. Microbiol. 14:305-310.

46. Zhilina, T.N., G.A. Zavarzin, F. Rainey, V.V. Kevbrin, N.A. Kostrikina, and A.M. Lysenko. 1996. Spirochaeta alkalica sp. nov., Spirochaeta africana sp. nov., and Spirochaeta asiatica sp. nov., alkaliphilic anaerobes from the continental soda lakes in central Asia and the east African rift. Int. J. Syst. Evol. Microbiol. 46:305-312. 